\title{
Funior Members Forum
}

\section{Health problems of ethnic minorities}

\author{
Call for board of science study
}

\author{
LINDA BEECHAM
}

What can a group of white professional people do to improve the availability of health care to the ethnic minorities in Britain ? Should the system be changed because $4.5 \%$ of the population have problems caused by language and social and cultural barriers ? It was generally agreed at the Junior Members Forum last month that access was inadequate and that the medical profession must bear some responsibility for this. The topic had been chosen as a result of some remarks made by His Royal Highness The Prince of Wales when he was installed as president of the BMA.1 "I believe," he said, "that we should not expect people to have to alter their lives drastically to be able to fit into the system that happens to exist." But as soon as a particular group, particularly if coloured, is picked out for special treatment then there are accusations of racism. The forum was told, for example, of a gynaecologist who had conducted a separate clinic for immigrant women and was reported to the Commission for Racial Equality. Yet he had acted on entirely altruistic grounds, believing that in this way he could devote time to them because of language and other difficulties.

The deputy chairman of the commission, $\mathrm{Mr}$ Clifton Robinson, pointed out all the disadvantages that ethnic minorities faced. He refuted the widespread but inaccurate assumption that because the National Health Service was free to all at the time of use it was equally available to all. Many sections of society found the NHS insensitive, inappropriate, and often irrelevant. The Service's response was to label them as problems rather than admit that the system was at fault. Ignorance, compounded by linguistic difficulty and social and cultural differences, made it difficult for them to avail themselves of the service. When they did they often faced prejudice and racism. It was estimated that $70 \%$ of Pakistani women in this country did not speak English. Mr Robinson pointed out that, as a large proportion of the ethnic minorities were young, the women were of childbearing age and used the general practitioner, paediatric, and maternity services. But many disliked being examined by men or women. He put to flight two commonly held myths. Firstly, there was the myth that the NHS could not discriminate against coloured people because so many of its employees were Afro-Caribbean or from the Indian subcontinent. But most of them were among the lowest paid workers and suffered discrimination themselves. Secondly, it was believed that members of the Health Service professions who belonged to ethnic groups were repositories of information about the countries from which they had come; often, however, there were wide social gaps between the professional workers and the patients.

What would happen to the immigrants when they got older, Mr Robinson asked. In their countries of origin they were accorded more respect the older they got: in this country they might be placed in homes for the elderly, and that might cause

British Medical Journal, London WC1H 9JR

LINDA BEECHAM, staff editor psychological problems. Turning to unemployment, $\mathrm{Mr}$ Robinson said that doctors had long been worried about its effect on health; they ought also to consider the effect on health of belonging to an ethnic minority. He hoped that the weekend's discussion would lead to doctors reappraising their attitudes and perceptions; otherwise the meeting would have been a waste of time.

\section{Language a major obstacle}

Agreeing that the medical profession had been slow to come to terms with the multicultural society, Dr Philip Rack, a consultant psychiatrist from Bradford, warned that the statement "black people have problems" could easily be misread "black people are problems." Language was, of course, one major obstacle. As a psychiatrist he was particularly conscious of the importance of communication since so much psychiatric diagnosis was based on the patient's subjective account rather than on physical signs. The various immigrant groups spoke numerous languages, but problems were sometimes created where none existed. Dr Rack recalled a telephone call from a police surgeon dealing with a difficult man in the cells. Was there anyone in the hospital, he asked, who could speak "West Indian."

There was, however, a great unmet need for medical interpreters in hospitals, clinics, and health centres. Few authorities had taken this seriously, and the Department of Health and

The BMA's Junior Members Forum met in Sheffield on 26 and 27 March, chaired by Dr Michael Rees, a senior registrar in radiology, who also chairs the Hospital Junior Staff Committee. On the first day of the weekend meeting five experts on the health problems of ethnic minorities spoke to the forum. A lively debate followed and the next day members approved some constructive resolutions aimed at alleviating the problems.

Another major debate was held on the board of science and education's report on the medical effects of nuclear war. The forum passed two motions on the subject.

"That this meeting, noting the report of the board of science and education on nuclear war, calls on the government to abandon civil defence planning against any nuclear attack and to redeploy the resources within the National Health Service."

"That this meeting believes that, in view of the fact that the health services and civil defence planning could not cope with the appalling devastation and human misery that would result from any nuclear attack on this country, there should be an immediate freeze on the number of nuclear warheads stationed in this country." 
Social Security had issued no guidelines. Dr Rack urged the BMA to apply some pressure on this subject. One aspect that he wanted to see tackled was the use of young children as interpreters: that was unethical and uncivilised. Often when interpreters were used, professional or otherwise, the exchange went beyond literal translation and the interpreter found himself trying to explain the doctor's view and doing the persuading.

Because of Britain's "tradition" of making sure that immigrants had a pretty miserable time for the first couple of generations many tended to live in inner cities and suffered from the disadvantages identified in the Black report ${ }^{2}$ of members of social classes IV and V. Many, for instance, found it difficult to take time off work to keep a surgery or hospital appointment. Undressing fully, consultation without the husband being present, hospital diets, visiting restrictions, prevention of religious observances, being without the familyall these were reasons that discouraged immigrants from going into hospital. Indigenous patients had been "trained" to submit without protest to such processes.

Dr Rack maintained that doctors were no more immune than the rest of the community to racism and racial prejudice. Doctors, nurses, health visitors, receptionists, and other staff all exhibited intolerance, impatience, and condescension at times. It was so easy to say, "Why can't these people conform ?"

\section{Social factors important}

Dr Carl Whitehouse is a general practitioner in Salford and a lecturer in the department of general practice in the University of Manchester. He agreed that assumptions and attitudes might be just as relevant to the health experience of ethnic minorities as any related to cultural factors. One ought to avoid the assumption, however, that their health problems were innate to the ethnic groups. Increased perinatal mortality or a high prevalence of tuberculosis could well reflect other social factors and be incidental to ethnicity.

General practitioners had to be aware of their patients' mobility and environment. For instance, the family structure of some of the resident ethnic groups might lead to considerable international travel and increased risk of imported disease, such as tuberculosis, whether from grandparents visiting here or from children going to Asia. The geographical distribution of ethnic minorities could also, Dr Whitehouse said, be a potent factor in their health experience. Variations in obstetric experience and perinatal mortality were sometimes related to cultural differences in diet or approach to antenatal care. While

\section{Proposals for improvement}

The forum passed several resolutions aimed at helping to solve some of the problems of the ethnic minorities.

- The board of science and education should examine and report on the action needed to meet the health needs of the ethnic minorities.

- The BMA council should (a) approach the relevant educational authorities with a view to introducing an appropriate medical undergraduate curriculum to improve awareness of the effect of racial and cultural differences on the delivery of health care to ethnic minorities; (b) establish links at local, regional, and national levels between the profession and organisations representing the health needs of ethnic minority groups; (c) explore ways to make health care more acceptable to ethnic minorities; $(d)$ explore ways to educate ethnic minority groups to make better use of existing provisions.

- The recruitment of health care professionals fluent in the language of the ethnic minorities should be encouraged. there was a higher perinatal mortality among Asians overall it was also high among patients of doctors who were not on the obstetric list and more Asians had doctors who were not on the list. Here, he suggested, was an area for research.

There were, of course, health differences related to culture, but the kind of service provided could also contribute to the health experience. It was obvious that there was a lack of information about what was available, and he thought that facilities like health visiting were probably incomprehensible to new arrivals.

\section{Examine attitudes}

The theme running through all the contributions was that, though it might be difficult, doctors and other Health Service workers had to examine their own attitudes if the service for ethnic minorities was to be effective. A senior lecturer in epidemiology at the University of Leicester, Dr Liam Donaldson, reported on an investigation in Leicestershire on the needs of an ethnic minority population as a whole rather than just those requiring services. He is surveying all district health authorities in England and Wales to find out what information is available to the Asian population and what service initiatives are being taken. He urged the BMA to support the idea of including an ethnic origin question in the next census because information now had to be gleaned from so many different sources; this hampered health planning. The composition of particular ethnic minority communities in terms of factors like age, sex, and the main cultural and religious groups was essential, in Dr Donaldson's view, to define health needs and structure services. But in the debates during the second day of the forum such a suggestion was turned down, several speakers arguing that it was an infringement of personal liberty.

In Leicester it had been decided to look in detail at one section of the Asian population-the elderly. The needs of elderly Asians had long been ignored on the assumption that Asian families cared for their elderly in such a way that outside intervention was unnecessary. As a proportion of the elderly population in the United Kingdom they were a small group, but, as $\mathrm{Mr}$ Robinson had already pointed out, their numbers would increase.

When it came to differences in the pattern of disease it was not only the traditional ones-such as tuberculosis, rickets, and malaria-that had to be considered but also the extent to which the ethnic minority population differed in the degree to which it experienced the diseases that afflicted modern societyfor example, heart disease, cancer, and strokes. Studies were hampered, however, because few health records contained valid information on ethnic groups.

How are white, professional, middle class people to learn about the way of life of the ethnic minorities? The last speaker, Ms Maggie Pearson, a research officer for the Centre for Ethnic Minorities Health Studies in Bradford, thought that information was always better coming from someone from the particular group concerned. She drew attention to the project on training in health and race that had been set up last year by the Health Education Council and the National Extension College. The project had been inundated with requests for training from professional people. It was too easy, Ms Pearson said, to see patients' differences as a problem and to attribute the lack of understanding to their apparent intransigence and unwillingness to assimilate British habits. But in her view many patients were making great efforts to accommodate the services in Britain.

\section{References}

1 Presidential address. His Royal Highness The Prince of Wales. Br Med $\mathcal{F}$ $1982 ; 285: 185-6$

${ }^{2}$ Department of Health and Social Security. Inequalities in health. London: DHSS, 1980. (Black report.) 